\title{
Spinal nerve roots contrast enhancement following anti-GD2 antibody therapy in neuroblastoma
}

Giovanni Morana, MD, PhD, Paola Lanteri, MD, Domenico Tortora, MD, Carola Martinetti, MD and Alberto Garaventa, MD

Neurology ${ }^{\circledR}$ 2018;90:895-896. doi:10.1212/WNL.0000000000005483
Correspondence

Dr. Morana

giovannimorana@gaslini.org

Figure Spine MRI findings
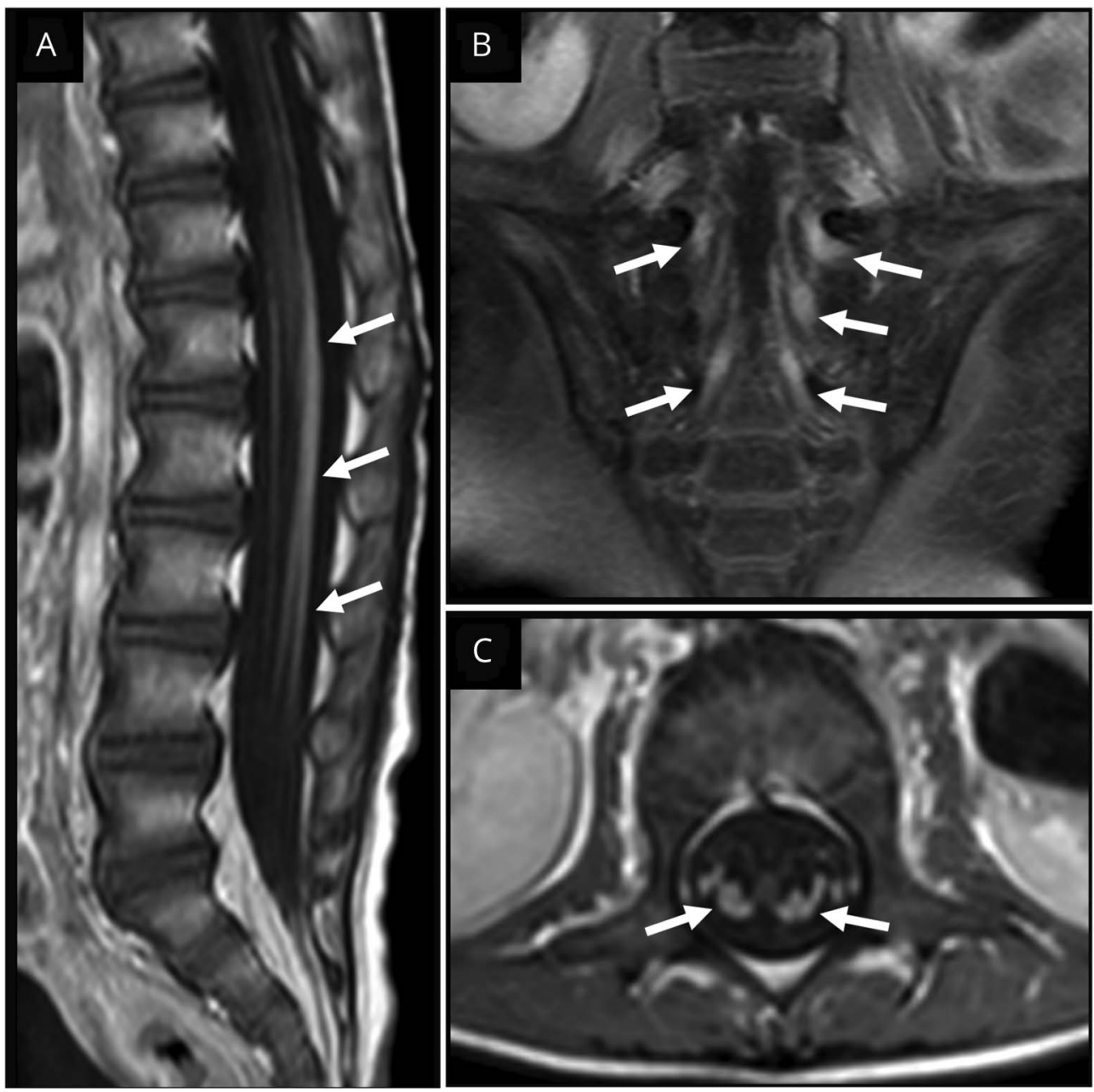

Contrast-enhanced sagittal (A), coronal (B), and axial (C) T1-weighted images show enhancing lumbosacral nerves (arrows, A, B) with almost selective involvement of the cauda equina dorsal roots (arrows, C).

A 2-year-old boy with grade IV neuroblastoma presented with acute neurogenic bladder and hyposthenia after 2 weeks of treatment with anti-ganglioside-GD2 antibody (GD2-Ab). Spinal MRI findings are shown in the figure. On nerve conduction studies, there was sensorimotor demyelinating polyneuropathy with secondary axonal features, without conduction block. CSF

From the Istituto Giannina Gaslini, Genoa, Italy.

Go to Neurology.org/N for full disclosures. Funding information and disclosures deemed relevant by the authors, if any, are provided at the end of the article. 
examination revealed albuminocytologic dissociation. Sensorimotor polyneuropathy is a potential neurotoxic effect of anti-GD2-Ab. ${ }^{1}$ Spinal nerves contrast enhancement might be related to the binding of anti-GD2-Ab to spinal nerves myelin, determining active myelin breakdown. Anti-GD2-Ab toxicity should be included in the differential diagnosis of spinal nerve root contrast enhancement in children. ${ }^{2}$

\section{Author contributions}

Giovanni Morana: drafting/revising the manuscript, study concept, acquisition of radiologic data. Paola Lanteri: drafting/ revising the manuscript, acquisition of electrophysiologic data. Domenico Tortora: drafting/revising the manuscript, study design, acquisition of radiologic data. Carola Martinetti: drafting/revising the manuscript, acquisition of radiologic data. Alberto Garaventa: drafting/revising the manuscript, study concept, study supervision.

\section{Study funding}

No targeted funding reported.

\section{Disclosure}

The authors report no disclosures relevant to the manuscript. Go to Neurology.org/N for full disclosures.

\section{References}

1. Yukia N, Yamadac M, Tagawaa Y, et al. Pathogenesis of the neurotoxicity caused by anti-GD2 antibody therapy. J Neurol Sci 1997;149:127-130.

2. Kontzialis M, Poretti A, Michell H, et al. Spinal nerve root enhancement on MRI scans in children: a review. J Neuroimaging 2016;26:169-179.

\section{Subspecialty Alerts by E-mail!}

Customize your online journal experience by signing up for e-mail alerts related to your subspecialty or area of interest. Access this free service by clicking on the "My Alerts" link on the home page. An extensive list of subspecialties, methods, and study design choices will be available for you to choose from-allowing you priority alerts to cutting-edge research in your field!

\section{AAN Wants to Help You with MIPS!}

MACRA and the Quality Payment Program and the 2018 Merit-based Incentive Payment System (MIPS) performance year began January 1. The AAN is committed to your success and has tools and resources to help you successfully meet your performance goals with minimal amount of effort. Take action today and visit AAN.com/view/QPP or email your questions tomacra@aan.com.

\section{The AAN Has Your Back!}

Every day, the AAN is fighting for you. From actively lobbying members of Congress for common sense legislation, to meeting with regulators to demonstrate the value of neurology and reduce regulatory hassles, the Academy is forcefully countering any threats to your profession and patient access to care. Learn more at AAN.com/policy-and-guidelines/advocacy, read the bimonthly Capitol Hill Report and monthly AANnews ${ }^{\circledR}$ member magazine, and respond to Advocacy Action Alert emails when we invite you to share your voice with Congress.

Get into the conversation at \#AANAdvocacy. 


\section{Neurology}

\section{Spinal nerve roots contrast enhancement following anti-GD2 antibody therapy in neuroblastoma}

Giovanni Morana, Paola Lanteri, Domenico Tortora, et al. Neurology 2018;90;895-896

DOI 10.1212/WNL.0000000000005483

\section{This information is current as of May 7, 2018}

\section{Updated Information \& Services}

References

Subspecialty Collections

\section{Permissions \& Licensing}

Reprints including high resolution figures, can be found at: http://n.neurology.org/content/90/19/895.full

This article cites 2 articles, 0 of which you can access for free at: http://n.neurology.org/content/90/19/895.full\#ref-list-1

This article, along with others on similar topics, appears in the following collection(s):

All Pediatric

http://n.neurology.org/cgi/collection/all_pediatric

Chemotherapy-tumor

http://n.neurology.org/cgi/collection/chemotherapytumor

Guillain-Barre syndrome

http://n.neurology.org/cgi/collection/guillainbarre_syndrome

MRI

http://n.neurology.org/cgi/collection/mri

Peripheral neuropathy

http://n.neurology.org/cgi/collection/peripheral_neuropathy

Information about reproducing this article in parts (figures,tables) or in its entirety can be found online at:

http://www.neurology.org/about/about_the_journal\#permissions

Information about ordering reprints can be found online:

http://n.neurology.org/subscribers/advertise

Neurology ${ }^{\circledR}$ is the official journal of the American Academy of Neurology. Published continuously since 1951, it is now a weekly with 48 issues per year. Copyright (C) 2018 American Academy of Neurology. All rights reserved. Print ISSN: 0028-3878. Online ISSN: 1526-632X.

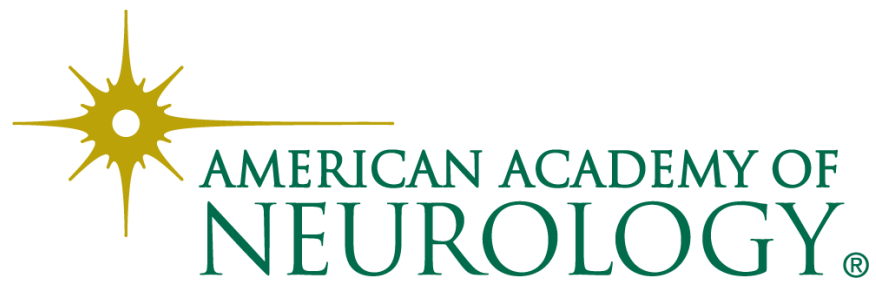

